\title{
ON THE BRANCH DEVELOPMENT IN FONTINALACEAE (BRYOPHYTA)
}

\section{О РАЗВИТИИ ВЕТОЧЕК У FONTINALACЕAЕ (BRYOPHYTA)}

\author{
ULYANA N. SPIRINA ${ }^{1} \&$ MichAEL S. IGNATOV ${ }^{2}$ \\ УЛЬЯНА Н. СПИРИНА ${ }^{1}$, МИХАИЛ С. ИГНАТОВ ${ }^{2}$
}

Abstract

\begin{abstract}
The branch primordia in Fontinalis, Dichelyma and Brachelyma are studied. The most common pattern in the family is that the outermost branch leaf is in 'eleven o'clock position', due to a reduction of the first branch leaf that starts to develop in 'four o'clock position'. Strong elongation of the stem and an extensive displacement of the branch primodium far from the leaf axil are probably the main factors of this reduction. However, in some species of Fontinalis the first branch merophyte produces lamina, either single or compound; at the same time, in F. hypnoides both the first and second branch leaves are reduced, so the outermost leaf is in 'twelve o'clock position'. The branch 'foot' formed of the bases of proximal branch leaves is discussed.
\end{abstract}

Резюме

Изучены зачатки веточек Fontinalis, Dichelyma и Brachelyma. Наиболее распространенным вариантом расположения веточных листьев является тот, при котором наиболее наружный находится в положении ' 11 часов циферблата', что связано с редукцией первого веточного листа, по-видимому, вследствие сильного растяжения стебля и смещения зачатка веточки относительно пазухи листа. Однако у некоторых видов Fontinalis первый веточный лист имеет развитую пластинку, простую или составную; в то же время есть виды, у которых обычно редуцируются и 1 и 2 веточные листья, так что наиболее наружный оказывается в положении ' 12 часов циферблата'. Обсуждается 'стопа', часто развитая в основании веточки, которая образована клетками оснований проксимальных веточных листьев.

KEYWORDS: anatomy, branching, Bryophyta, development, Fontinalis, Brachelyma, Dichelyma

\section{INTRODUCTION}

The present paper continues our study of the structure and development of branch primordia in pleurocarpous mosses. The position of the first branch leaf is of particular interest, as it was found to be a quite conservative character allowing to solve some problems in pleurocarp systematic at the familial level. An example of the Brachytheciaceae and Meteoriaceae (Ignatov, 1999) shows how this helped to delineate of the family volume as well as identify a close relationship of these two families. The latter conclusion was done basing on a single, but very constant synapomorphic character: the first branch leaf ('pseudoparaphyllium') points downwards (Ignatov, 1999), contrary to the most common pattern where the first branch leaf is lateral, designated by Ignatov \& Hedenäs (2007) as 'four o'clock' position (Fig. 1).

Later, however, the former pattern was found not to be confined to these two families, but characteristic also the for Leucodontaceae (Spirina \& Ignatov, 2010). Similarity of branch primordia

1 - Biological Faculty, Tver State University, Zhelyabova 33, Tver 170100 Russia - Россия 170100 Тверь, Желябова, 33, Тверской государственный университет, Биологический факультет; e-mail: ulayspirina@mail.ru

2 - Main Botanical Garden of Russian Academy of Sciences, Botanicheskaya 4, Moscow 127276 Russia - Россия 127276 Москва, Ботаническая, 4, Главный ботанический сад РAH, e-mail: misha_ignatov@list.ru 
Fig. 1. Eearly stages of branch development in most pleurocarpous mosses: a schematic summary of Berthier (1971).

F1-4-order of stem leaves; * - branch initial cell, later - apical cell of branch, 1-3-order of branch leaves.

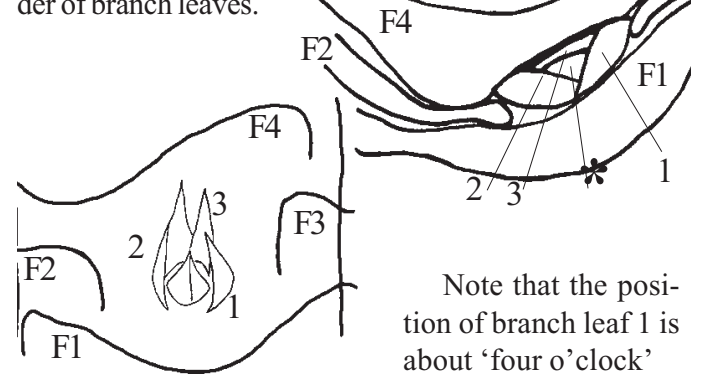

structure in these families was explained by similarity in ecology, rather than by common origin.

Another example of the same pattern was illustrated for Fontinalis antipyretica Hedw. (Müller, 1898; Ruhland, 1924): this picture is reproduced here in Fig. 2. Bertier (1971) commented that this pattern was possible in Fontinalis due to a reduction of the first and then also the second branch leaves, although in the summary table he described Fontinalis as having always only one leaf reduced, except for the case of stolons where the first leaf appeared in 'four o'clock position', i.e. like in most of pleurocarpous mosses. Ignatov (1999) did not find the pattern shown in Fig. 2 in Dichelyma, another genus of the Fontinalaceae. Fontinalis itself was not mentioned, because it was difficult to interpret the arrangement of most proximal branch leaves due to 'leafless' branch base in more or less developed branches (cf. Figs. 3, 5) and even dormant branch primordia (Fig. 6), where leaves are shifted up to the branch base.

Better understanding of a position of the most proximal branch leaves in the genus Fontinalis and other members of the Fontinalaceae was one of the main aims of the present paper. The second unusual character is the leafless 'stub' at the base of more or less developed branches (Figs. 3-6). Its homology has not been discussed in literature, to our knowledge, but the understanding of this

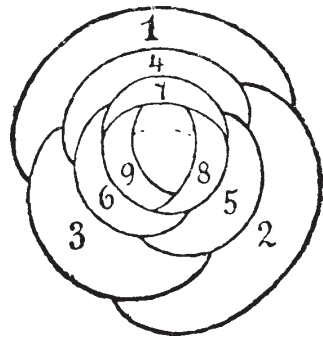

Fig. 2. Eearly stages of branch development in Fontinalis (reproduced from Müller, 1898; the same illustration is given by Ruhland, 1924). Note that the first developed branch leaf is in 'twelve o'clock position'.

structure is important, as the 'absence of pseudoparaphyllia' (the latter term is commonly applied to most proximal branch leaves) is often considered as an important for pleurocarp taxonomy.

These aspects of Fontinalis development remained somewhat controversial, despite this genus being in a focus of studies since the famous 'Moosstudien' of Lorents (1864) and 'Der Wachstum der Stengel in der Fontinalis' of Leitgeb (1868). The Leitgeb's observation, however got a strong criticism from Bertier (1971).

\section{METHODS AND MATERIAL}

The stem apical parts of ca. $5 \mathrm{~mm}$ in length were isolated, and after removing the external leaves, were fixed in 4\% glutaraldehyde for 5 days, post-fixed with $1 \%$ osmium tetroxide in Na-phosphate buffer, $\mathrm{pH}=6.8$, for $10 \mathrm{~h}$. The material was then dehydrated in $70 \%$ ethanol, stained in uranilacetate ( $2 \%$ solution in $70 \%$ ethanol for 10 hours), and then dehydrated through a graded ethanol/ acetone series to $100 \%$ acetone. After that samples were embedded in araldite 6005 medium, according to the protocol of manufacturer.

Sections were cut $2 \mu \mathrm{m}$ thick with glass knives, put on glass slides without mounting medium.

Sections were photographed under Leitz and Olympus CX41 light microscopes with transmitted light, and some sections were stained by berberin and photographed under Olympus CX41 with fluorescence on $\lambda=488 \mathrm{~nm}$.

Supplementary photographs were made under SEM LEO-430 and fluorescent Olympus C41 microscopes.

Most cross sections were done from the herbarium collection of Fontinalis antipyretica Hedw., from Tver Province, 20.VI.2009, coll. Spirina (MHA).

Additional herbarium specimens studied:

Brachelyma subulatum (P. Beauv.) Schimp. ex 

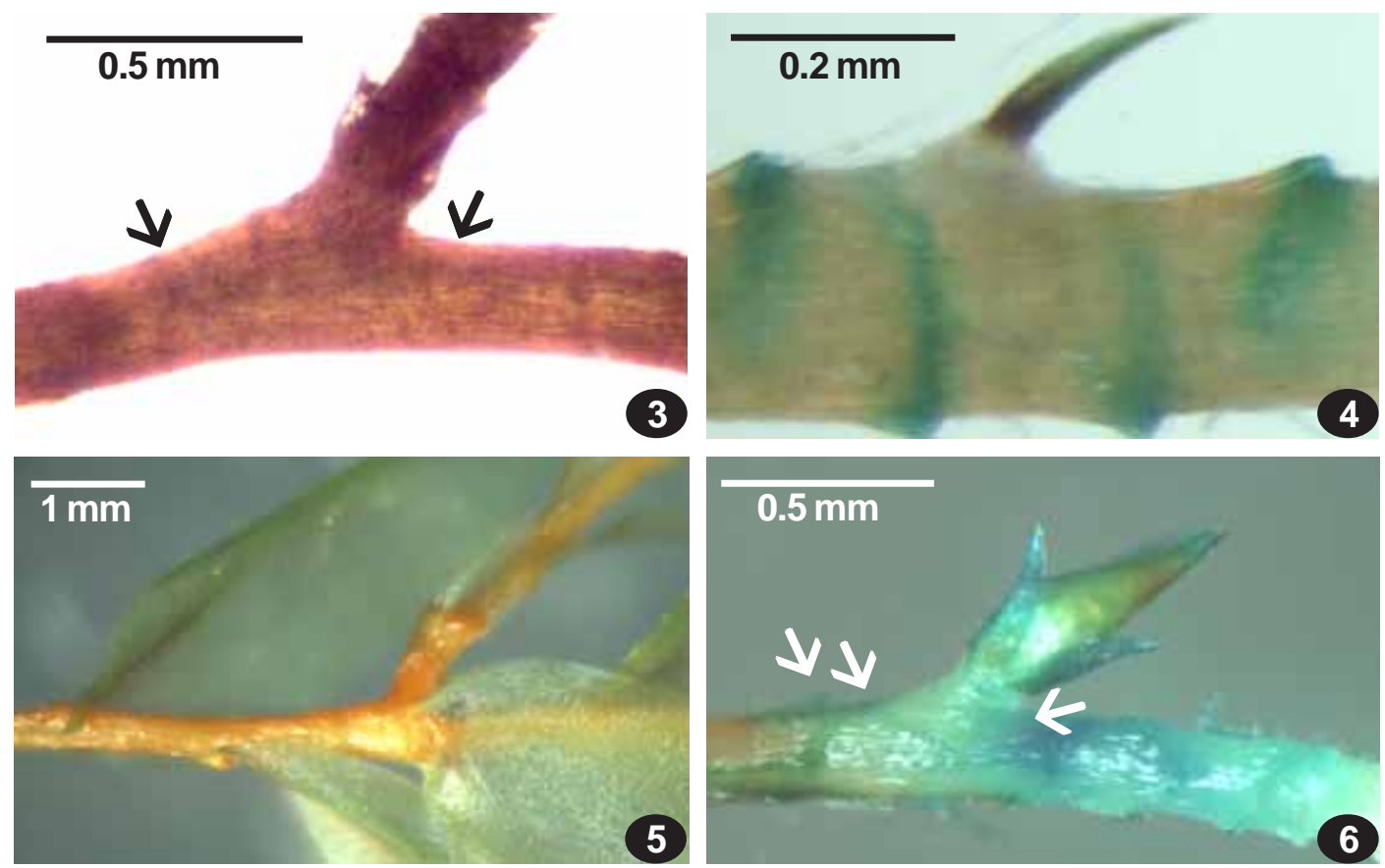

Figs. 3-6. Branches / primordia in Fontinalaceae, showing leafless area at branch bases: 3 -F. hypnoides (Surgut, Czernyadjeva \& Kuzmina); $4-$ F. neomexicana (California, Shevock); 5. F. antipyretica (Orenburg, Zolotov \& Spirina); 6 -Dichelyma falcatum (Leningrad Prov.). Arrows point the upper and lower borders of 'branch foot' (discussed on page 135).

Card.: U.S.A., Florida, 28 Dec. 1990, Allen \#9929 (MHA);

Dichelyma falcatum (Hedw.) Myr.: Russia. Leningrad Prov., 9 Sept 1954, I.I. Abramov \& A.L. Abramova s.n. (MHA).

Fontinalis antipyretica: Russia: Orenburg Province, 4.VI.2004, Zolotov \& Spirina s.n. (MHA); Sakhalinskaya Prov., Kunashir, Ignatov\#06-1396(MHA).

F. dalecarlica Bruch et al.: U.S.A., Pennsylvania, 29 March 1986, Allen s.n. (Allen's Fontinalaceae Exs. 39) (MHA); U.S.A., New Hampshire, 30 Aug 1992, P. \& A. Redfearn \#37853 (MHA).

F. flaccida Ren \& Card.: U.S.A., Florida, 4 Dec. 1988, Allen, Buck \& Harris (Allen's Fontinalaceae Exs.42) (MHA).

F. hypnoides Hartm.: Russia, Tyumen Prov., Surgut, 18 Aug 2000, Czernyadjeva \& Kuzmina \#98 (MHA).

F. hypnoides (missourica expression) - U.S.A., Missouri, 25 Sept. 1990, Allen \#9876 (MHA).

Fontinalis neomexicana Sull. \& Lesq., U.S.A., California, 5 Oct. 2009, Shevock \#33728 (MHA); Aug. 1989, M. Ignatov (MHA).

F. novae-angliae Sull.: U.S.A., Maine, 12 June
2007, Allen\#28117 (MHA ex MO).

Fontinalis sullivantii Lindb., U.S.A., Maryland, 12 June 1994, Allen \#15596 (MHA).

\section{Cross section picture presentation}

Note 1. Presented sections are all $2 \mu \mathrm{m}$ thick.

Letters on pictures correspond to the section numbers and do not always go in order, as some sections in a series are omitted. This allows to calculate how many microns between the shown sections are.

Note 2. In case of two types of images, from light and fluorescenst microscopy, highlighting different details, both of them are presented. Such pictures have the same number, but marked by ', e.g., 1 and 1 '.

Note 3. In horizontal views of stem or leaf its apex is always to the right.

Note 4. Numerals in figures indicate number of branch merophyte [numbering includes the underdeveloped ones, which position is indicated sometimes by number in square brackets], asterisk $\left(^{*}\right)$ points the apical cell; $\alpha$. indicates axillary hairs and cells that produce them. 


\section{RESULTS}

Longitudinal sections of a number of specimens collected in summer have a plateau-like apical area, with an angle of $120^{\circ}$ at the ${ }^{\wedge}$ apex (Figs. 7-8), where leaves are somewhat retained in their development. In classical schemes of Leitgeb (1868) and Müller (1898) an apex is considered to be conic, with sides forming an angle of ca. $90^{\circ}$, and such structure occurs in some of our specimens (Fig. 10). Some specimens, e.g., one from the Kuril Islands collected in autumn, have a narrowconic apical part $\left(<70^{\circ}\right.$, cf. Fig. 9). It seems to be obvious that an intensive growth (especially in a cold season of the year) may modify strongly the shape of the stem apical part.

As it is seen in the longitudinal sections, the stem apical cell size is 35-40 $\mu \mathrm{m}$ long, 20-25 $\mu \mathrm{m}$ wide (Figs. 7-8). A similar and rather short proportion has a branch apical cell (Fig. 11). The stem apical cell is tetrahedral in shape and in transverse section through the uppermost part of stem it has a shape of rectangular triangle (Figs. 12-13).

Since about the 20th leaf from the apex, leaves start to grow very fast and form a 'dome' above the 'apical plateau'. Leaves are very densely arranged within the 'apical plateau', but becoming quite spaced already at the level of ca. 40th leaf from the apex (Fig. 8).

The apical cell cuts off new merophytes at an angle of $120^{\circ}$, notwithstanding its rectangular triangle shape (Figs. 12-13). It is likely that a longer side is faced to the merophyte that is under separation at moment, although this explanation needs better confirmation, whereas the photographs of a wet stem apex without leaves (Figs. 9-10) do not show the angular shape of the apical cell.

At a very short distance from the apex, ca. 50 $\mu \mathrm{m}$, the branch initials appear in transverse sections, as big cells at the leaf abaxial surface. They are apparent also on longitudinal-oblique sections (Figs. 16A-E), where it is visible that the first division of a branch initial cell happens at ca. $80 \mu \mathrm{m}$ from the stem apex. Section transverse to branch primordia (Fig. 15) shows that the first division occurs in the same way as in most mosses (Fig. 1); note however that the leaf spiral may be right or left ${ }^{1}$. The position of the first division can be understood also from the series of cell sections already within the 'apical plateau' (Fig. 14), where the first division is seen only in sections $2 \mu \mathrm{m}$ above leaf axil (cf. Figs. 14D and 14 C), and is no longer visible at section $4 \mu \mathrm{m}$ above leaf axil (Fig. 14B).

Large cells differentiated from the abaxial side of leaves form the stem below the leaf and also branch primordia in some 'internodes'. At a distance of ca. $90 \mu \mathrm{m}$ from the stem apex branch primordia have already differentiation into a branch apical cell and 2-3 first branch merophytes (Fig. 17). Apical branch cell (marked by asterisk *) is widely exposed to the stem surface, ca. $28 \mu \mathrm{m}$ long. Another large cell (marked with \#) proceeds the differentiation into stem sclerodermis only: its divisions are not oblique, but parallel and perpendicular to the stem surface.

The development of the first branch merophyte in Fontinalis antipyretica can be illustrated by the series shown in Fig. 18 (cf. also Fig. 11) and Fig. 19. In the former, the bud is still sitting in the leaf axil, and the absence of space between the bud and the leaf below results in a poor development of the first branch leaf that is not raised above the stem surface. The subsequent elongation shifts the bud to a certain distance up from the axil, and cells of the first branch merophyte starts to divide, mainly in transverse direction to the stem length (Fig. 19I' \& J').

Some views of young branch primordia near the stem apex in Fontinalis anipyretica (e.g., Figs. 20-21) allow to see the first branch leaf, or at least its outline that cover the third branch leaf (that is in 'twelve o'clock position') by its upper corner (arrowed in Figs. 20-21). At later stages, there is usually no trace of any leaf structures in the position where the first leaf should be (this case is illustrated in Fig. 30 for Dichelyma falcatum).

The first branch leaf is however retaining and well seen in Brachelyma subulatum (Figs. 27-29), Fontinalis dalecarlica (Figs. 33-34) and F. neomexicana (Figs. 31-32, 35C), and in mosses with slender stature, e.g., F. sullivantii (Fig. 35B).

(text continued on page 128)

1 - Contrary to the statement in Goffinet et al. (2009) that the spiral is always left, in many pleurocarps (e.g., in Brachytheciaceae, the spiral in the next sympodial branch has an opposite direction against parental axis). In Fontinalis the right spiral occurs as well, although the left one is more common. 

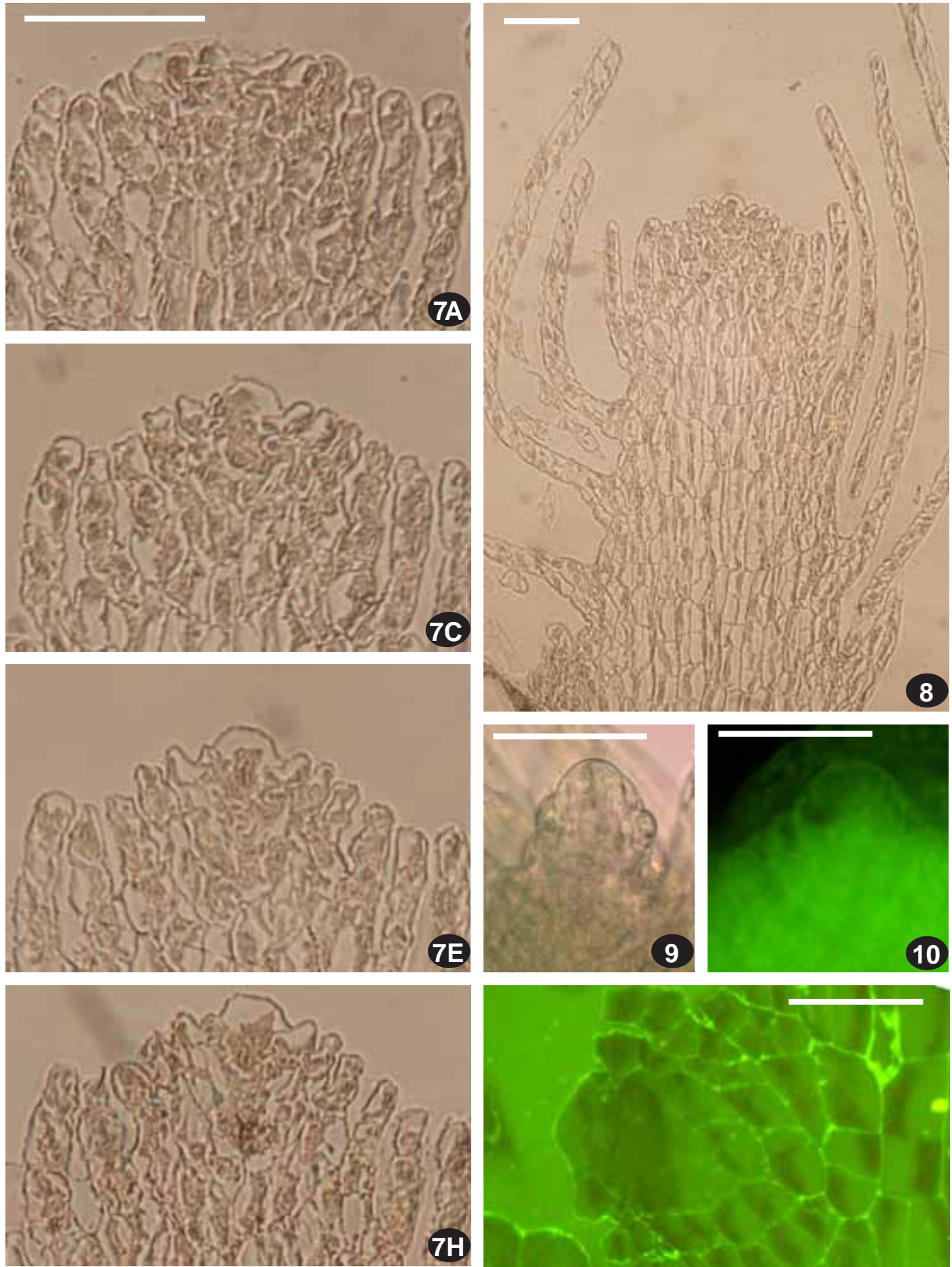

Figs. 7-11. Apical cells in Fontinalis antipyretica (78, 11 - Tver; 9-10 - Kunashir). 7-8 - longitudinal section through or near stem apical cell; 9-10 - stem apices after leaf removal; 11 - longitudinal section through branch apical cell. Scale bars $50 \mu \mathrm{m}$.

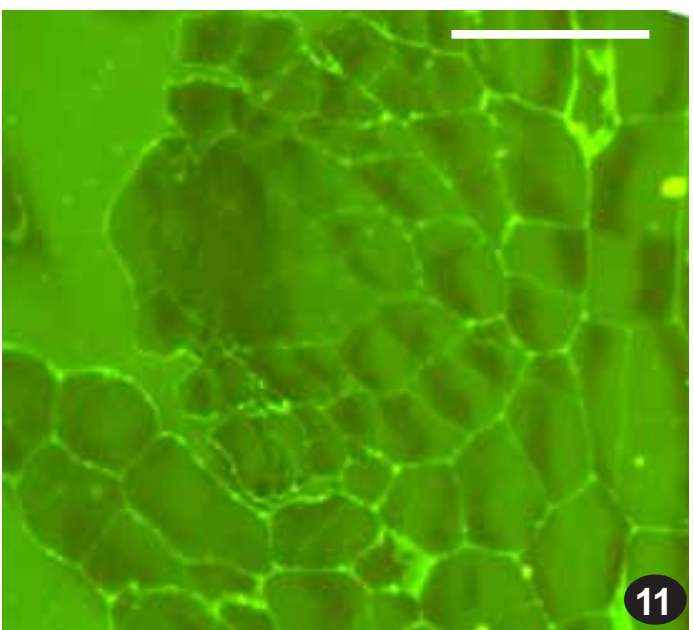



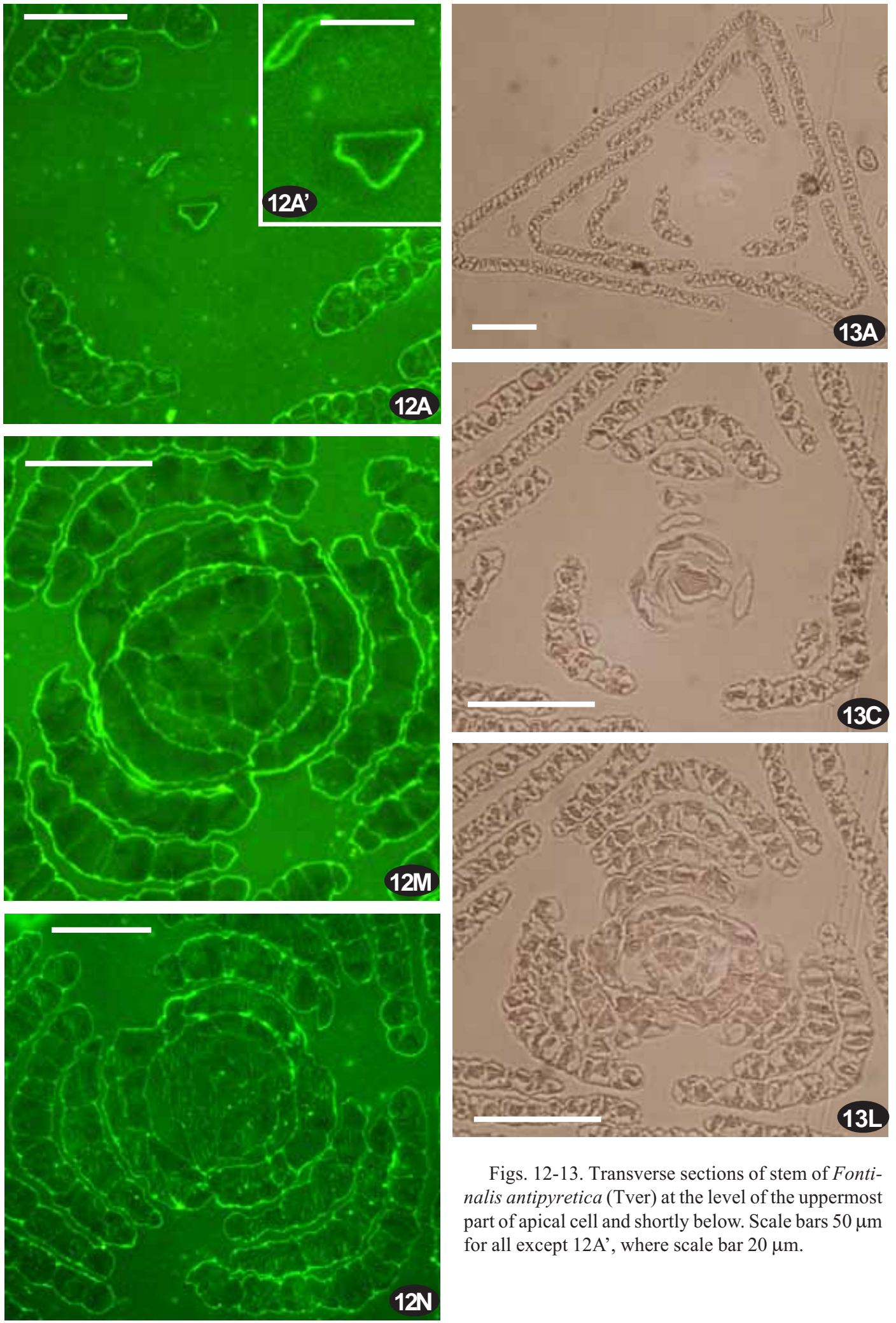

Figs. 12-13. Transverse sections of stem of Fontinalis antipyretica (Tver) at the level of the uppermost part of apical cell and shortly below. Scale bars $50 \mu \mathrm{m}$ for all except 12A', where scale bar $20 \mu \mathrm{m}$. 

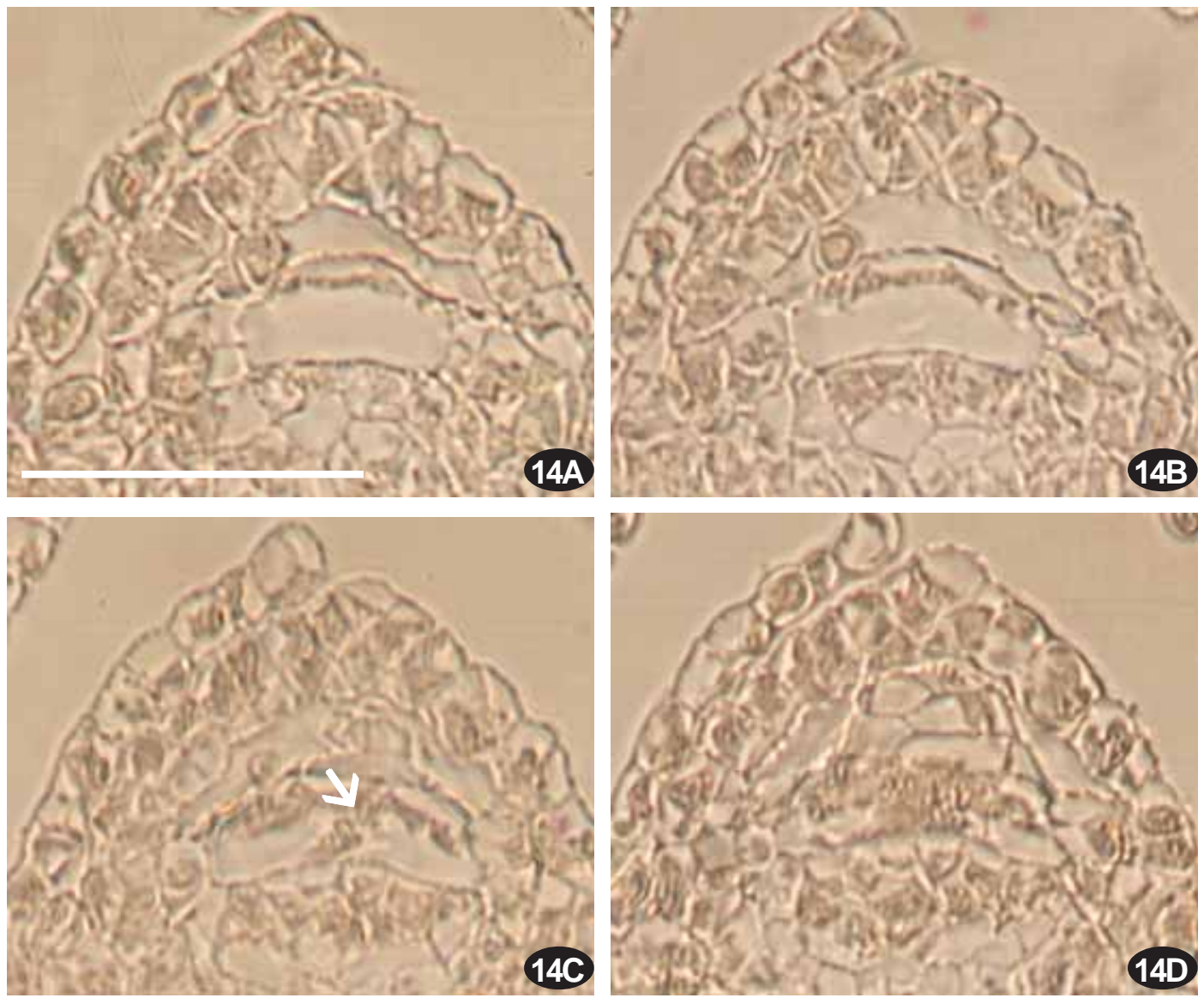

Fig. 14. Fontinalis antipyretica (Tver): sections longitudinal to stem and transversal to large cell differentiated on leaf abaxial surface (cf. Fig. 12N). The 14A is closest to central part of stem. Note absence of divisions in large cell in 14A and 14B, while the cell is divided near its proximal side (14C), producing almost equal cells. Scale bar $50 \mu \mathrm{m}$.
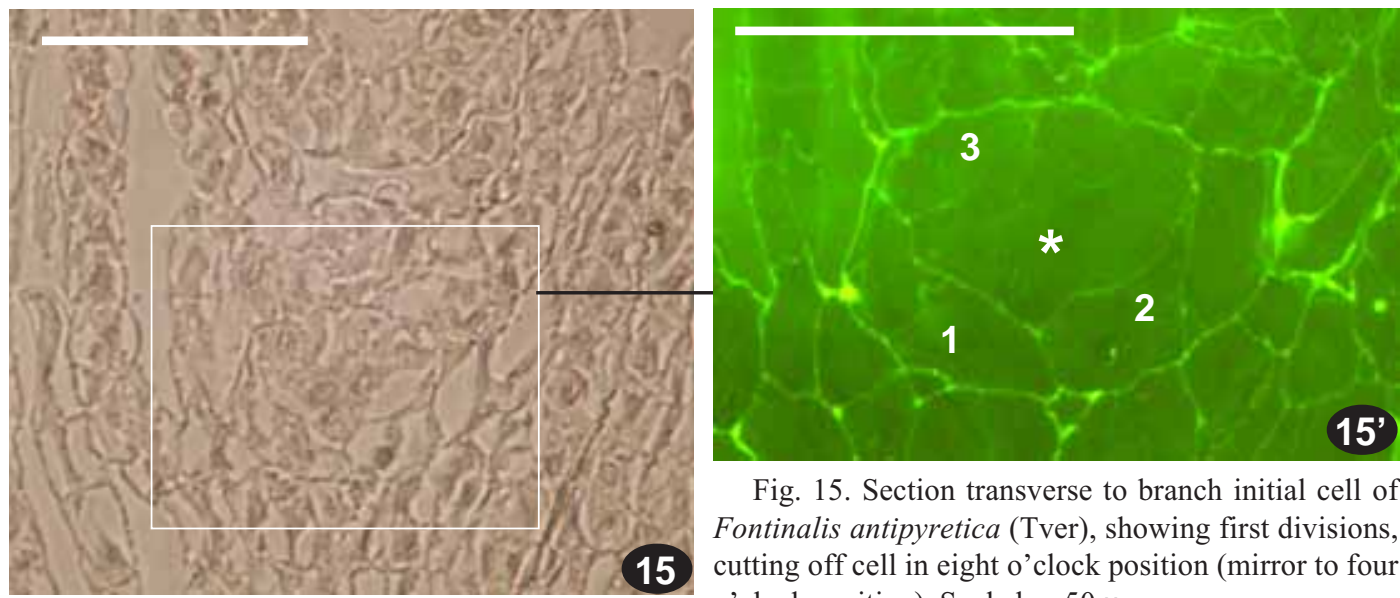

Fig. 15. Section transverse to branch initial cell of Fontinalis antipyretica (Tver), showing first divisions, cutting off cell in eight o'clock position (mirror to four o'clock position). Scale bar $50 \mu \mathrm{m}$. 

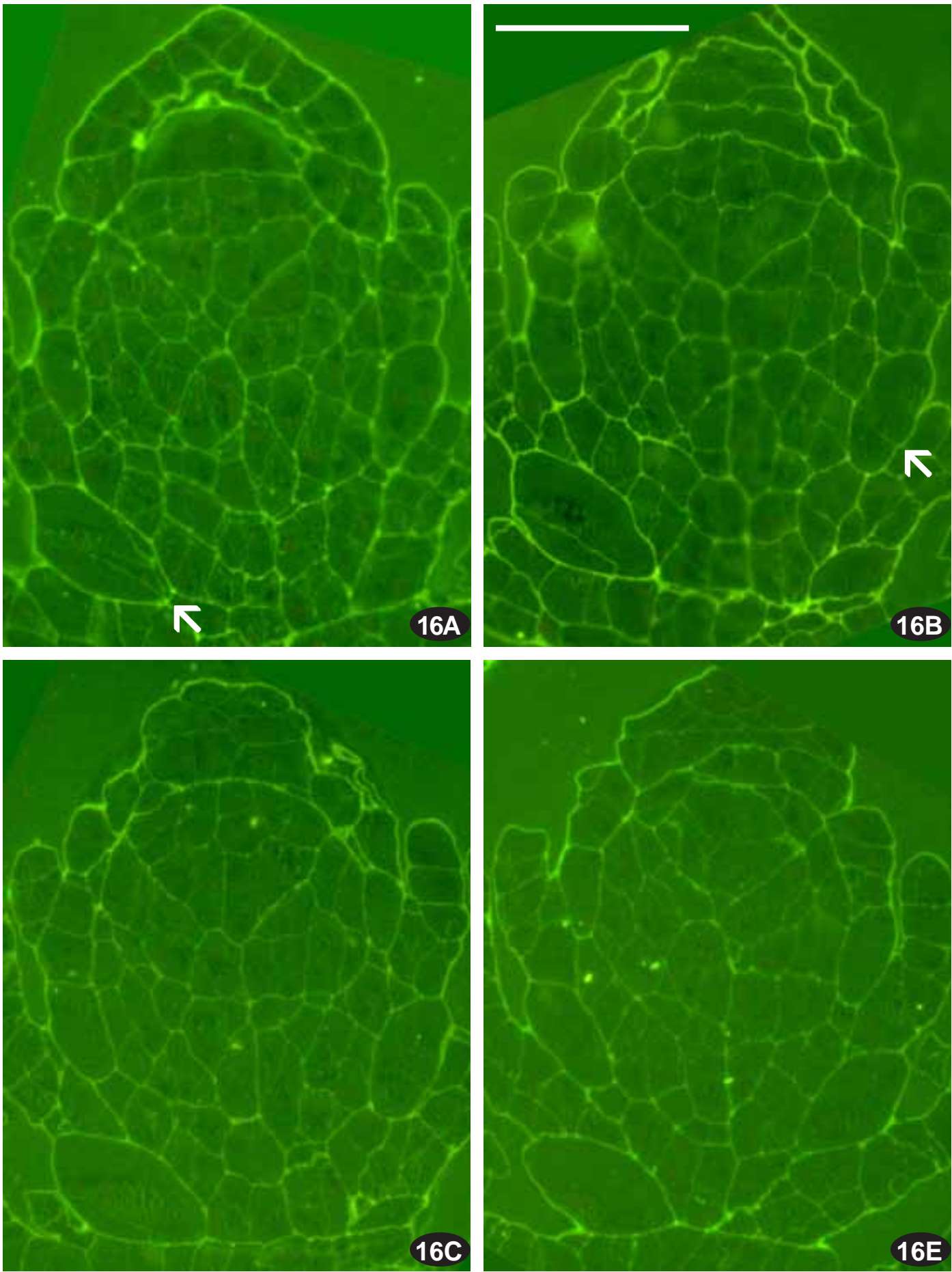

Fig. 16. Longitudinal and slightly oblique section of stem of Fontinalis antipyretica (Tver). Large cells below leaves have either transverse division (arrow in 16B), or oblique (looks like longitudinal in individual sections), arrowed in 16A (well seen also in 16B and 16C, but disappering in $16 \mathrm{D}$, due to oblique position). The former and latter cosserpond to cells forming 'internode' without and with branch inital correspondingly, compare also with cells in Fig. 17, marked by * and \#, correspongdingly. Scale bar $50 \mu \mathrm{m}$. 

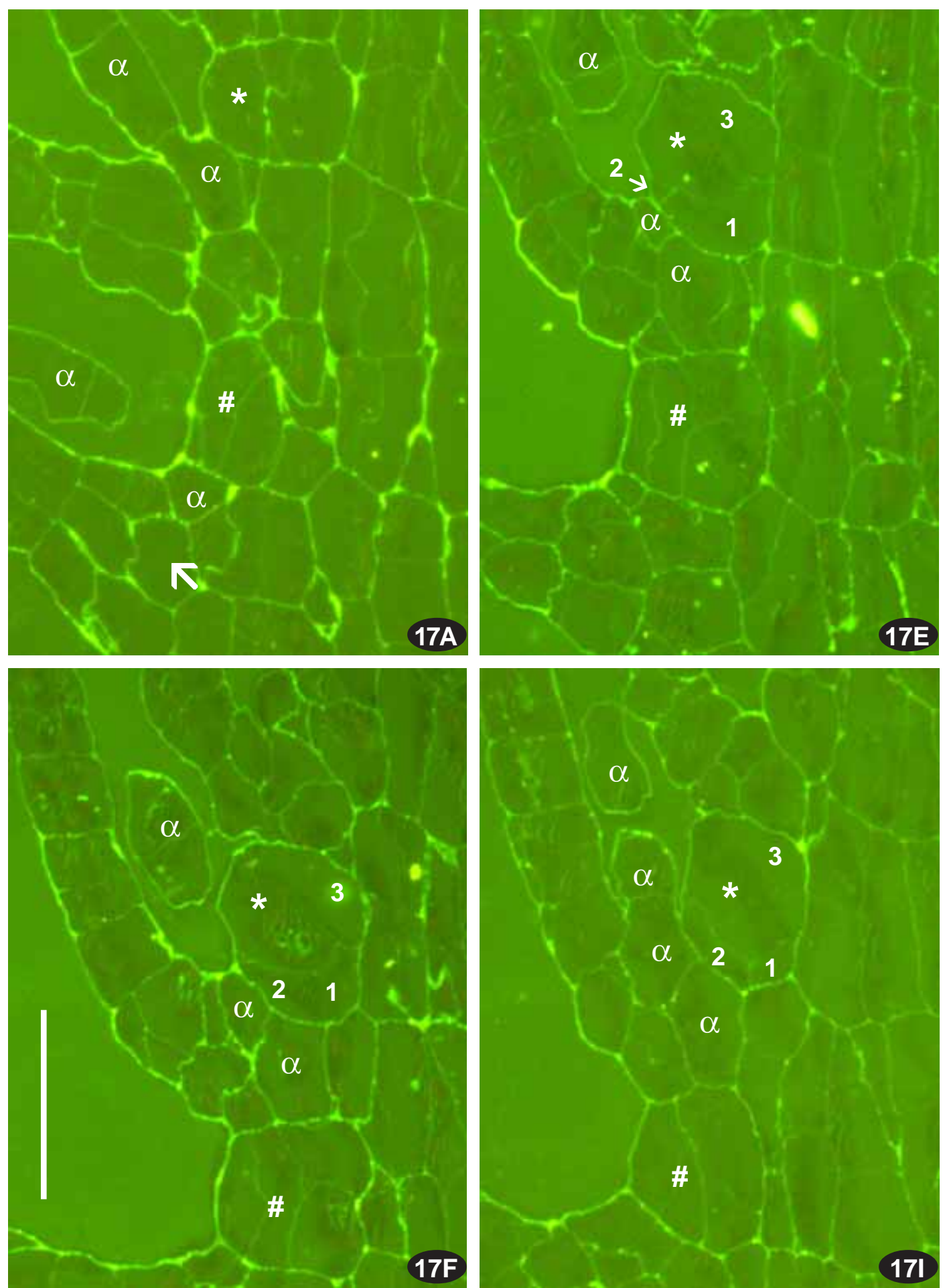

Fig. 17. Longitudinal section of stem of Fontinalis antipyretica (Tver). Large cells below leaves exhibit either differentiation into branch bud (cell above marked by asterisk) or to 'internode' without bud (cell below marked by \#). Compare also with Fig. 16. Note also multistratose leaf base (arrow). Axillary hairs and cells of belt that produce axillary hairs are marked by $\alpha$. Scale bar $50 \mu \mathrm{m}$. 

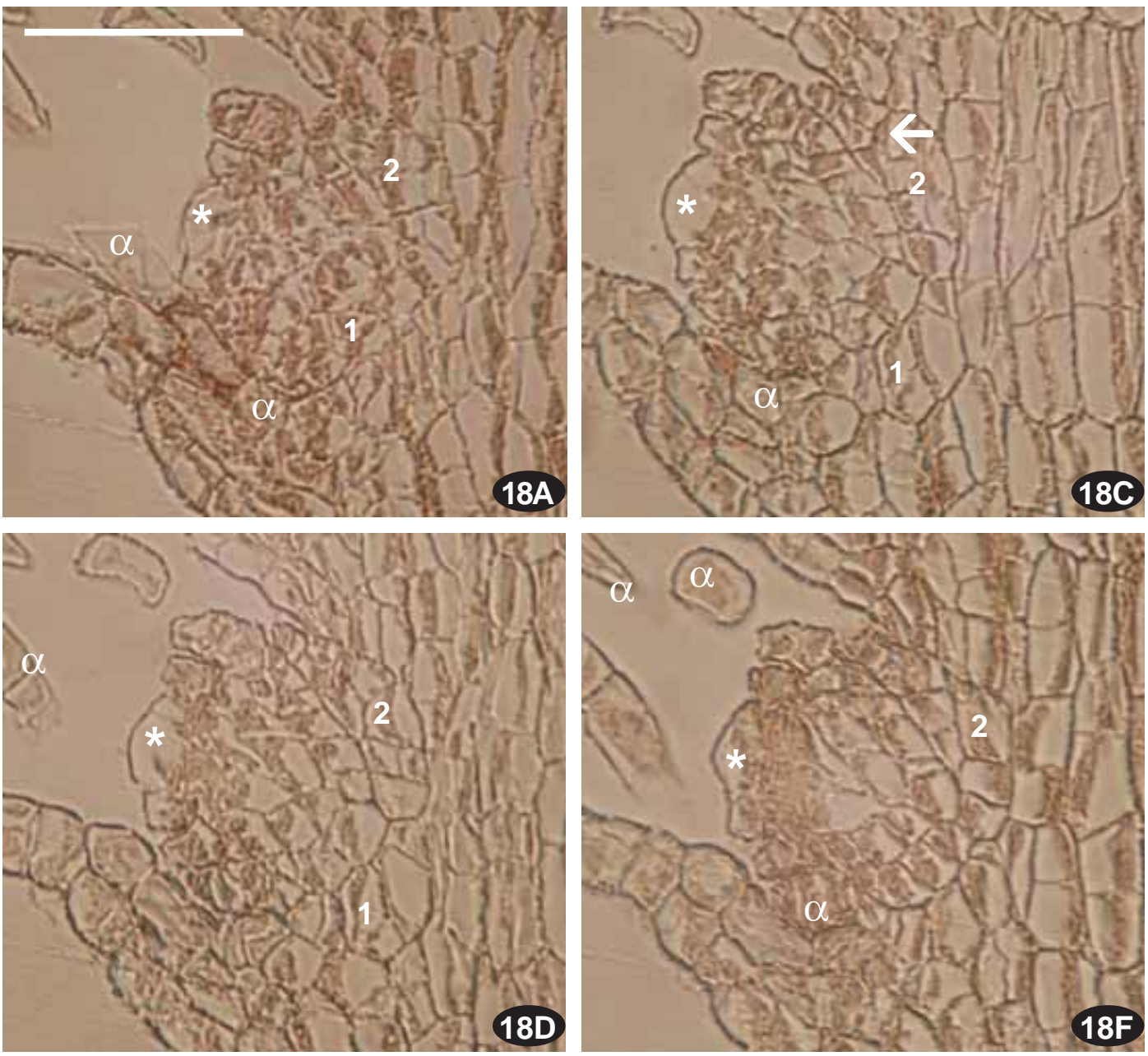

Fig. 18. Longitudinal section of stem and branch primordium of Fontinalis antipyretica (Tver), showing a stage when branch primordium is not yet shifted above leaf axil. Compare with Fig. 11 which corresponds to $18 \mathrm{M}$ (not shown here) of this series of sections. Scale bars $50 \mu \mathrm{m}$.

In all these cases, first branch leaf often appears to be just as a low ridge (Figs. 34, 35B) or 'compound', i.e., formed by a number of lamina that are connected, cf. Figs. 27-28 (and then looks like furcate or laciniate proximal branch leaves of, e.g., Hypnum cupressiforme, cf. Spirina \& Ignatov, 2008) or disconnected, cf. Figs. 29, 31 (and then similar to the case of, e.g., Thamnobryum, cf. Akiyama \& Nishimura, 1993; Ignatov \& Hedenäs, 2007).

In Fontinalis antipyretica in slender plants, as well as in branch initials on branches near their ends, the first branch leaf is sometimes present, at least as a very low ridge (similar to that of $F$. dalecarlica shown in Fig. 34).

Similar ridges were commonly found also at base of branch primordia that represent perigonial buds. Even if there is no direct evidence of the nature of the latter, they can be recognized by their position in the axil of leaf next to leaf with branch in its axil. This conclusion can be made because the primordia of vegetative branches occur in Fontinalis in axils of every fourth (F. squamosa) or every seventh (F. antipyretica) leaf, according to Correns (1899). Our observations confirm this in general, but find that branch primordia in every fourth leaf are the most common case in the genus (e.g., in F. hypnoides, F. dalecarlica, F. neomexicana), and it is present is some $F$. antipyretica collections as well.

The second merophyte is originally in "eight 

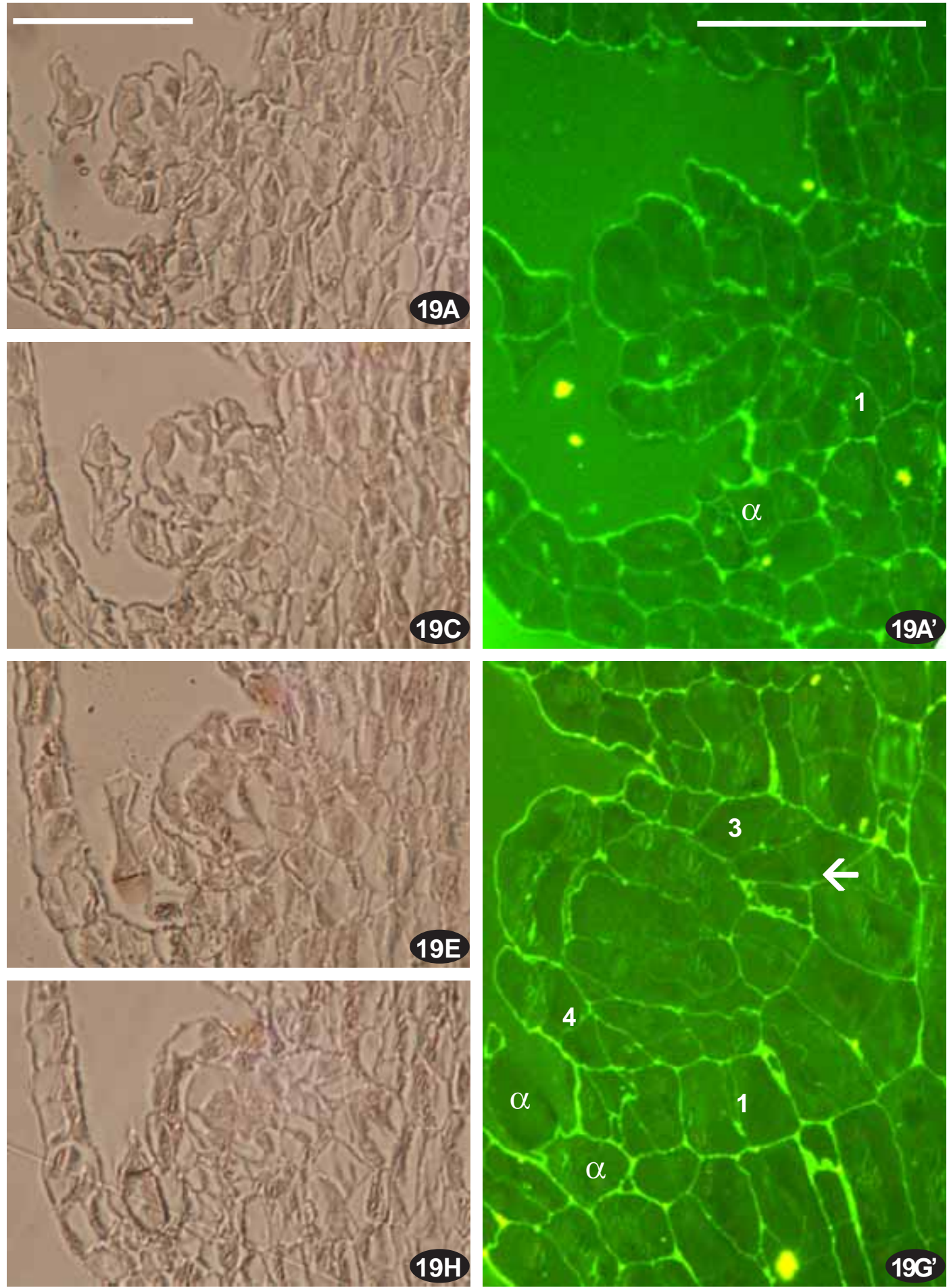

Fig. 19. Longitudinal section of stem and branch primordium of Fontinalis antipyretica (Tver), showing a stage when branch primordium is shifted up to $20-30 \mu \mathrm{m}$ above leaf axil. The cells of belt that produce axillary hairs are marked by $\alpha$. Arrow points the base of the fourth branch leaf. Scale bars $50 \mu \mathrm{m}$ (continued on page 129). 

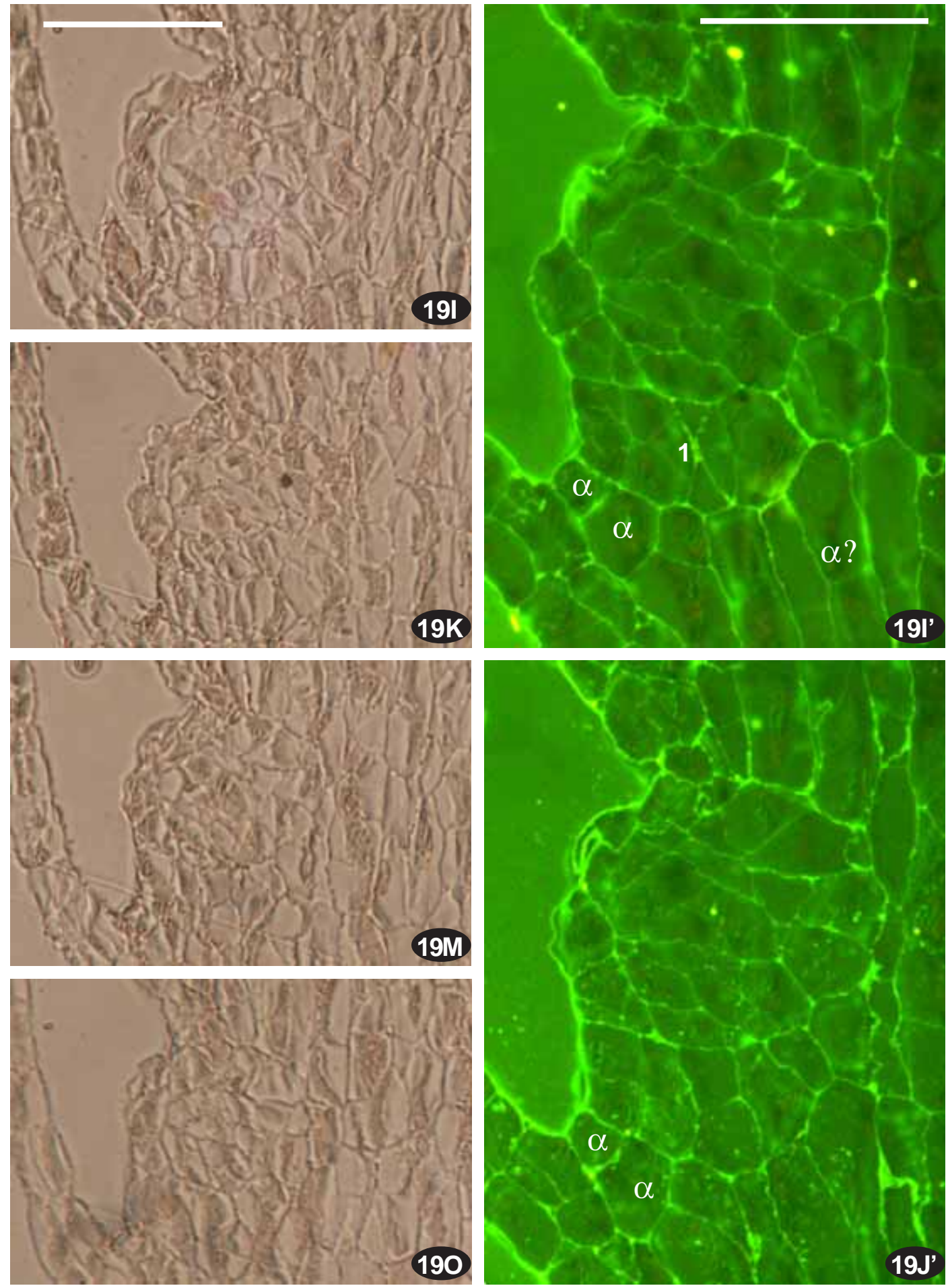

Fig. 19 (continued from page 128). Longitudinal section of stem and branch primordium of Fontinalis antipyretica (Tver), showing a stage when branch primordium is shifted up to $20-30 \mu \mathrm{m}$ above leaf axil. The cells of belt that produce axillary hairs are marked by $\alpha$. Scale bars $50 \mu \mathrm{m}$. 

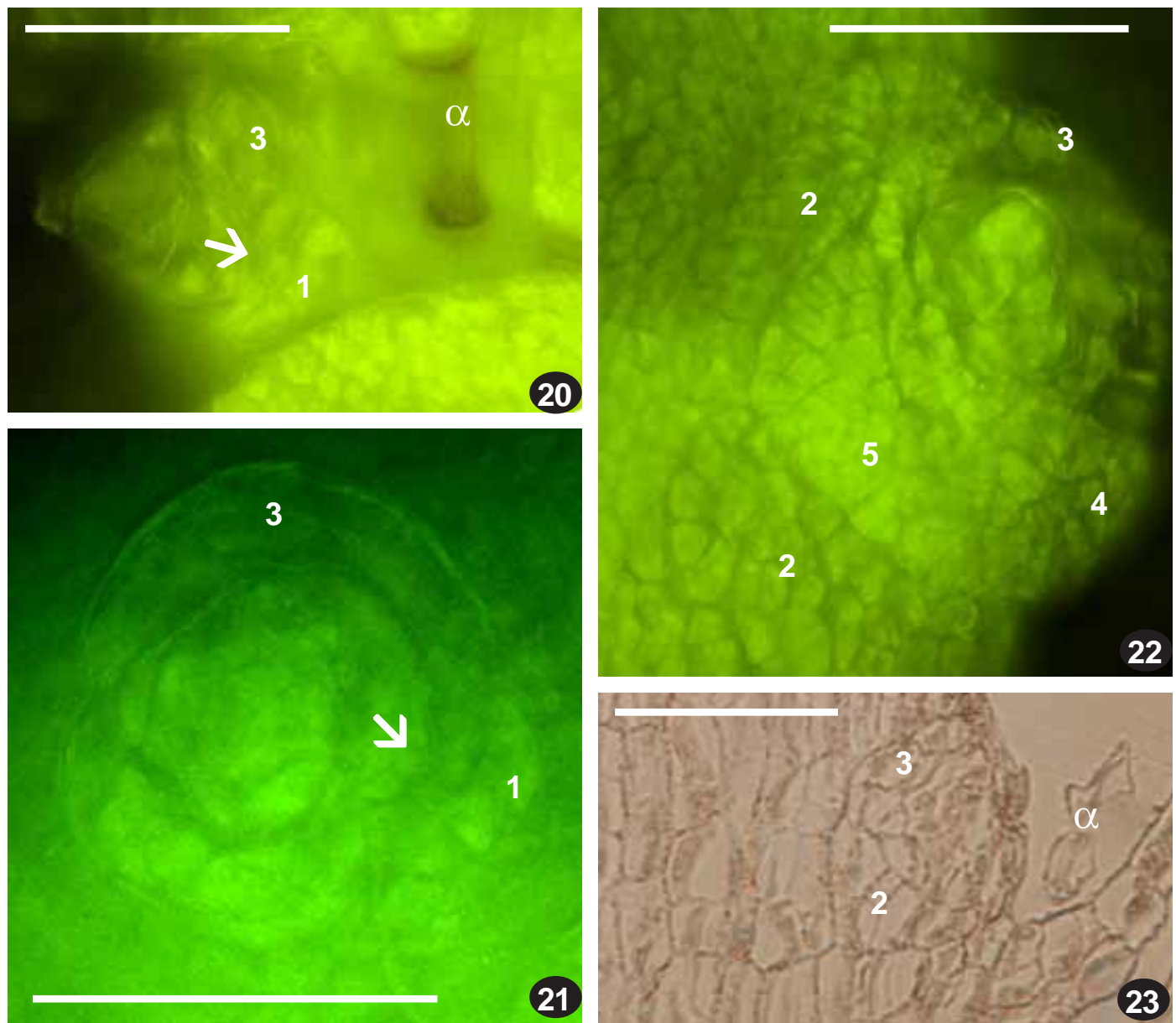

Figs. 20-23. Branch primordia of Fontinalis antipyretica (20-22: Kunashir; 23: Tver). 20 - early stages where first leaf can be outlined in four o'clock position; 21 - tangential and longitudinal section, showing cell left and below branch primordium of the second merophyte; 22 - later stage where leaves are seen as low ridges; note that the primordium already quite shifted from leaf axil and structures that could be referred to the first branch leaf are absent. Axillary hairs are marked by $\alpha$. Scale bars $50 \mu \mathrm{m}$.

o'clock position' (Figs. 22-23), but subsequently it shifts to 'eleven o'clock position' as a low ridge (Fig. 22) or more or less normally developed leaf (cf. Fig. 28, 30-32, 35B, C). A low ridge is a characteristic of an early stage of development in $F$. antipyretica, and usually it develops further forming a well-developed leaf, although shorter than the third one and a subsequent branch leaf (thus similar to, e.g., Dichelyma case illustrated in Fig. 30). However, in a few cases we have observed the second branch leaf more strongly reduced and retaining only as a low ridge near branch bases, e.g., Fig. 35A for F. novae-angli$a e$. As the second branch leaf is difficult to dis- cover in this case, the overall structure of branch primordium may be assumed as the case illustrated by Müller (1898) and Ruhland (1924), and shown here in Fig. 2.

The same case with the outermost branch leaf in 'twelve o'clock position' has never been observed by us in $F$. antipyretica, but it has been found in many branch primordia of $F$. hypnoides, although sometimes the second branch leaf was observed in this species as well.

In Brachelyma subulata branch initials often have two subfilamentose structures (Figs. 25-26) around an undeveloped branch initials similar to 'paraphyllia' in Leptodon and Leskea (cf. Igna- 

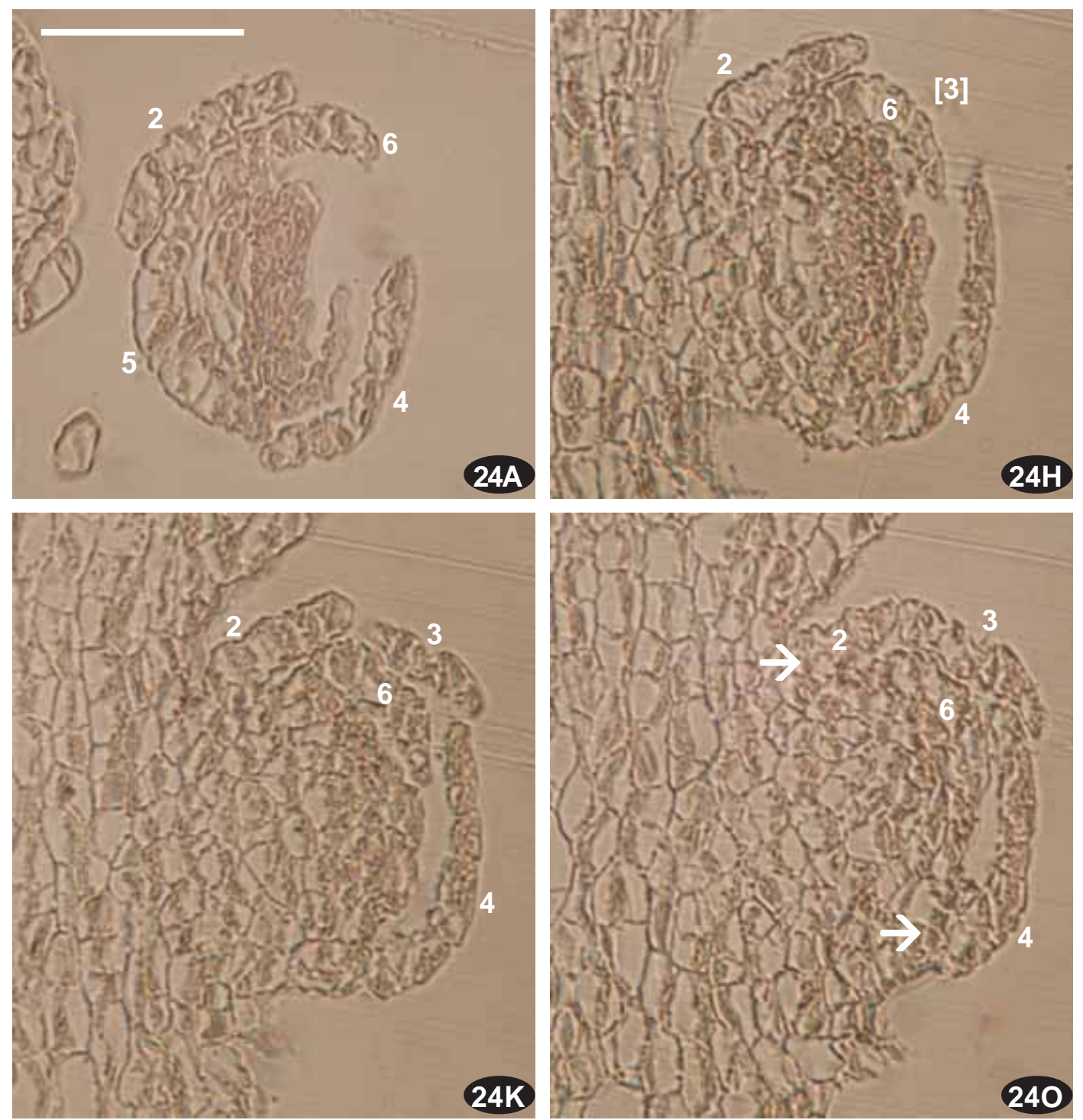

Fig. 24. Branch primordium of Fontinalis antipyretica (Tver): tangental-longituginal section, allowing to see the sequence order of leaves by their overlappings; no structure can be attributed to the first branch leaf. Scale bar $50 \mu \mathrm{m}$.

tov \& Hedenäs, 2007). Their homology with first and second branch leaves (but strongly thinned due to almost underdeveloped branch primordium) can be understood due to the position between decurrencies of two neighboring leaves, i.e. the same place where the developed branch primordium occurs when it is present. These subfilamentose structures can be observed near more developed branch primordia, although they are not always seen and sometimes are represented by only one such structure, side by side with de- currency (and thus difficult to be recognized for its homology).

Fig. 24 shows the sequence of leaves of an early differentiated bud where the first leaf is reduced, while the outermost is the second one. The primordium is very young, ca. $200 \mu \mathrm{m}$ from the stem apex, sitting between leaves that are still not spaced. However the branch leaf bases are already apparently bi- and partly tristratose (Fig. $24 \mathrm{O}$, arrowed). The multistratose bases of stem 

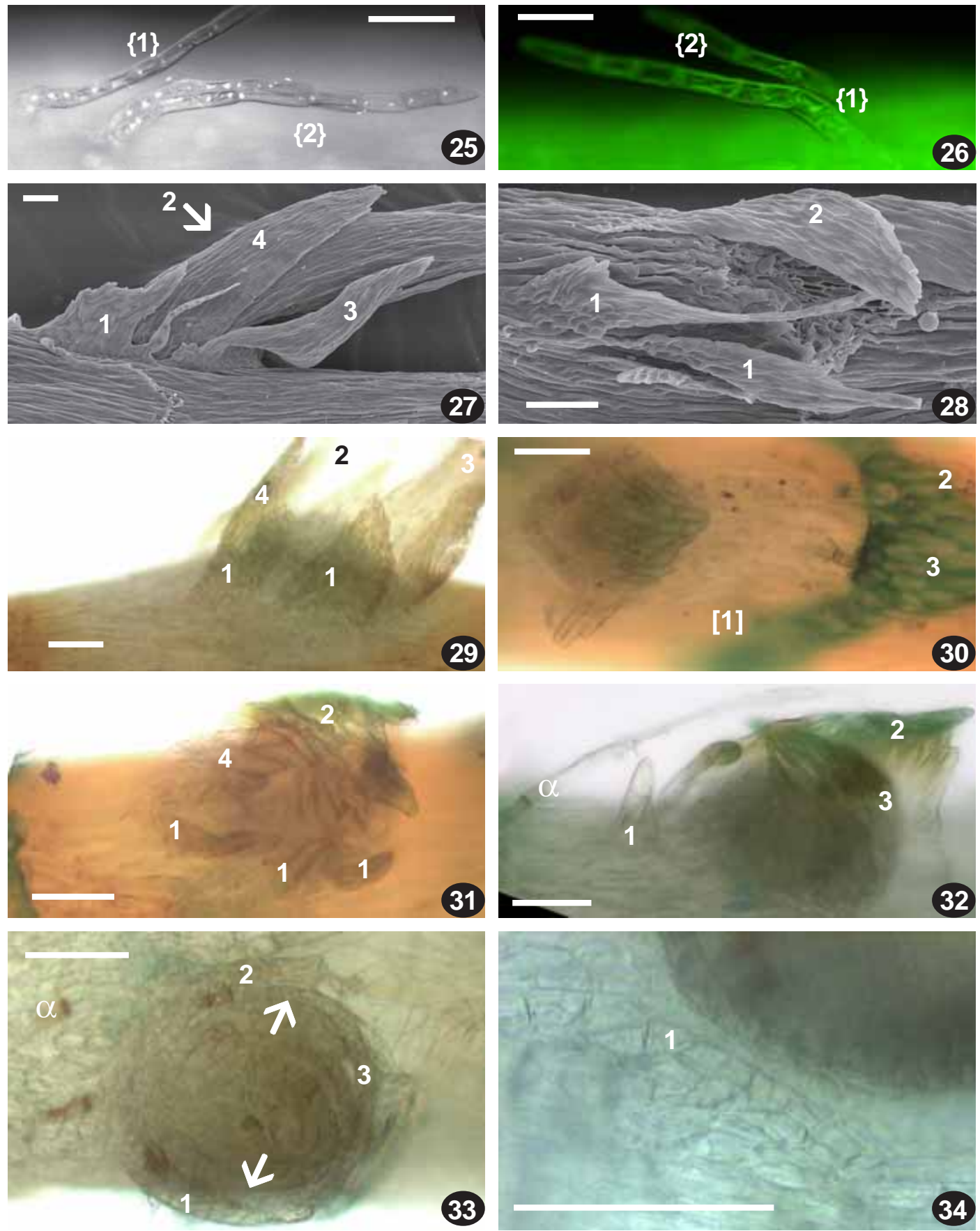

Figs. 25-34. Branch primordia in Fontinalaceae: 25-29:Brachelyma subulatum: 25-26 - subfilamentose first and second branch leaves around almost undeveloped branch primordium ('paraphyllia', cf. text); 30 - Dichelyma falcatum (Leningrad Prov.), front view of branch primordium, showing $2 \mathrm{~d}$ and $3 \mathrm{~d}$ branch leaves, while the 1 st one is totally reduced; 31-32 - Fontinalis neomexicana (California), showing compound first branch leaf in 4 o'clock position or strongly reduced simple first branch leaf in the same 4 o'clock position; 33-34 - Fontinalis dalecarlica (33: New Hampshire, August; 34: Pennsylvania, late March]: branch primordium at early stage (still in leaf axil), with 1st and $2 \mathrm{~d}$ branch leaves covering $3 \mathrm{~d}$ one (arrowed); and low ridge of cells in four o'clock position near branch primordium, thus interpreted as remnants of the first branch leaf. Scale bars $50 \mu \mathrm{m}$. 


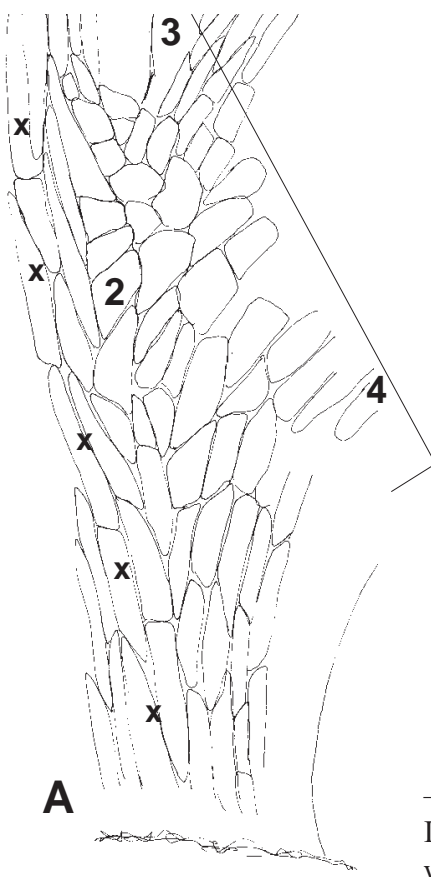

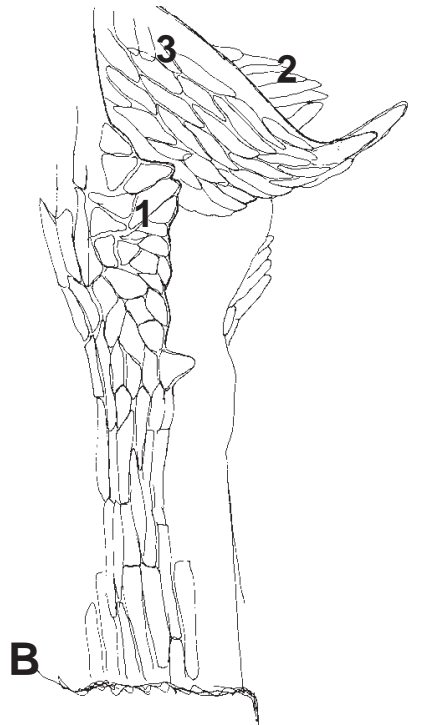

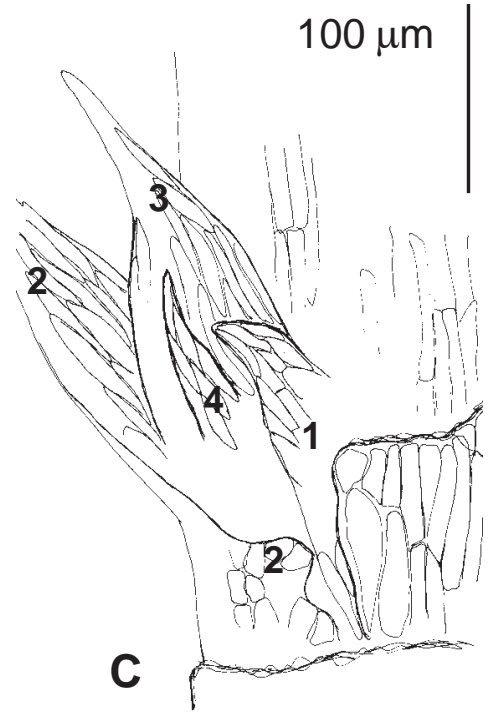

Fig. 35. Branch primordia in Fontinalaceae: A: Fontinalis novae-angliae; B: - F. sullivantii; C: F. neo-mexicana. Cells of decurrency are marked by $\mathrm{x}$ in $35 \mathrm{~A}$. In $35 \mathrm{C}$ decurrency of branch leaf 2 has protrusions closer to leaf in axil of which the primordium is sitting; decurrency of branch leaf 1 can be traced to the axil of this leaf.

leaves can be seen in many sections (e.g. Fig. 17, 18 ), and even better seen in the place of leaf detaching on the stem (e.g., Fig. 30). Bases of ranch leaves seem to be unistratose only at the earliest stages of their development, while sometimes at the very early stage the bistratose parts of the leaf base can be seen (Figs. 18C, 19G').

The sections through bases of mature branches (Figs. 4, 6) are shown in Figs. 36-37. They definitely indicate that the 'stub' at branch base is composed of branch leaf bases, and moreover, the branch base also 'decurrents' on stem, forming there a branch 'foot', sometimes of quite an extensive area (arrowed in Figs. 3, 6).

\section{DISCUSSION}

First divisions of the branch apical cell show that they are going in an order typical for all pleurocarps, as well as many acrocarpous mosses (cf. Fig. 1). However in mature stems no leaf or even its traces in the position of first branch leaf is performed, that confirms Bertier' (1971) conclusion about the reduction of the first, and sometimes also of the second leaf.

Contrary to the Brachytheciaceae and Meteoriaceae where the pattern of leaf arrangement around branch primordia is very stable (Ignatov,
1999), and the Leucodontaceae, where it is quite stable (Spirina \& Ignatov, 2010), the Fontinalaceae species are very plastic in this character. The presence and absence of the first branch leaf can be sometimes observed within one shoot, although most examined specimens had the identical pattern within one collection.

It seems that the degree of reduction of the first and then the second branch leaf correlates with the degree of stem elongation, which is obvious as the part of stem between branch pimordium and the leaf below it belongs to branch first merophyte. In less elongated places of stem, where branches are denser (including fertile zones), or growing slower approaching their maximal length, or in plants more slowly growing in summer, the degree of reduction is less compared with fast growing shoots.

Also one can observe a correlation that the denser are leaves in different species, the more common is presence of the first branch leaf. The constant presence of the latter was noted in Brachelyma subulatum (6 leaves $/ \mathrm{mm})^{1}, F$. neomexicana (2 leaves $/ \mathrm{mm}$ ), and it was usual in F. dalecarlica (2-3

\footnotetext{
1 - the leaf density is calculated from the specimens used for first branch leaf study
} 

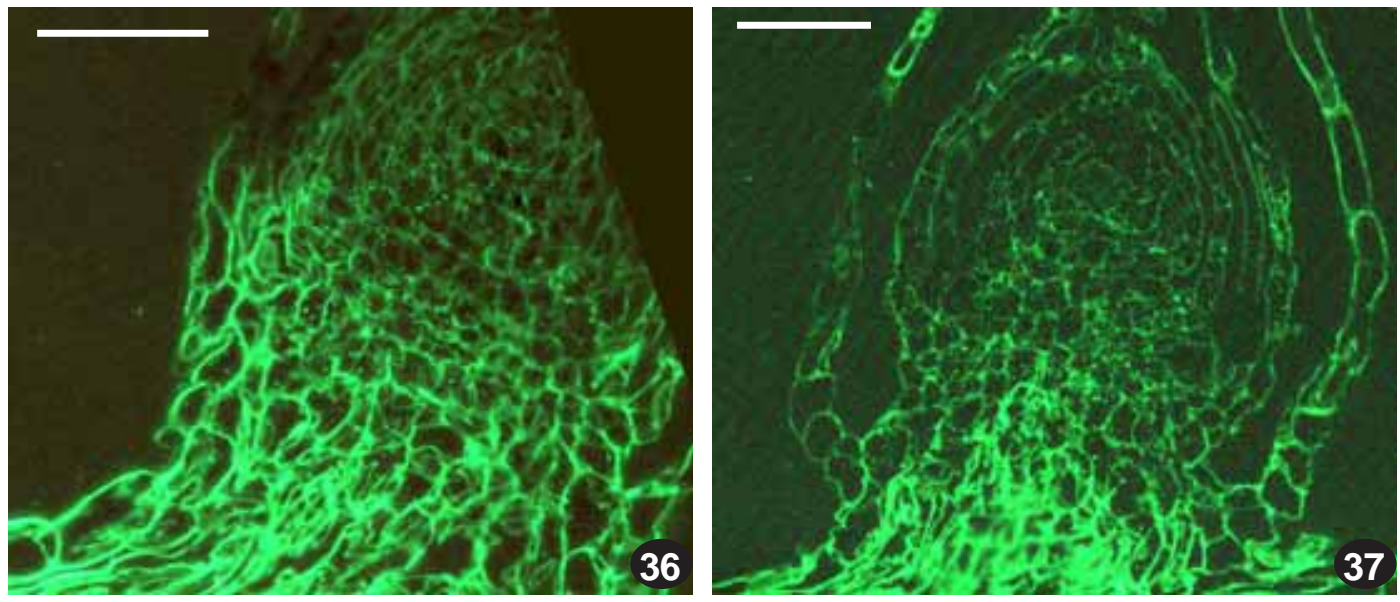

Fig. 35. Branch primordia in Fontinalis antipyretica (aquarium culture), from the middle part of stem (3-5 cm from stem apex), showing large cells (basal parts of merophytes of third to ca. tenth branch leaves). Scale bar $50 \mu \mathrm{m}$.

leaves $/ \mathrm{mm})$, although sometimes in a strongly reduced state (Fig. 34).

The absence of the first and the presence of the second branch leaf is a characteristic of species with leaves more distant along the stem: $F$. antypyretica $(0.4$ leaves $/ \mathrm{mm}), F$. flaccida $(0.3$ leaves/mm), $F$. sullivantii (1 leaf/mm), although Dichelyma falcatum (2 leaves $/ \mathrm{mm}$ ) provides an exception in this group.

Both the first and second branch leaves are absent in many (although far from all) promirdia of F. hypnoides (0.6 leaves $/ \mathrm{mm})$, and occasionally in F. novae-angliae ( 0.5 leaves $/ \mathrm{mm})$.

Within the single species the variation in development of first branch leaf is observed in:

a) F. antipyretica, where the better developed branch leaves are seen on the ends of branches, at base of perigonial primordia and, according to Bertier, on stolons.

b) F. dalecarlica, where better developed branch leaves were seen in collection made in March, comparatively with one made in August.

Glime (1987a) and Glime \& Raeymaekers (1987) study of growth in Fontinalis species have revealed a strong difference in growth rates in different seasons of the year, depending on the water temperature. Fast growth in spring is much more active than is summer, as an optimal $t^{\circ}$ for Fontinalis is $+15^{\circ}$, while $+20^{\circ} \mathrm{C}$ stops its growth almost totally in summer. The growth starts in autumn, which is easy to observe in herbarium spe- cimens: late autumn collections have a narrowly acute stem apex (e.g., Fig. 9), while slow summer growth agrees with a plateau-shaped apex (Figs. 7-8). Thus it is quite expected that in the late summer collection of $F$. dalecarlica, the first branch leaf is better developed (Fig. 34) than in the time of active growth in March (Fig. 33).

Noteworthy is also that the maximal reduction was observed in F. hypnioides s.l. (incl. F. duriaei) which according to Glime (1987b) has the fastest growth ever recorded not only in the genus, but likely also among all mosses.

An unusual stem anatomy in Fontinalis has been noted already by Lorentz (1864), who indicated that its cells structure is more similar to acrocarpous mosses. The important difference between acrocarps and pleurocarps (cf. Frey, 1970) is in the shape of the stem apical cell (short in the former, longer in the latter) and, correspondingly in the angle to the stem length formed by rows of cells (as they appear on longitudinal stem section). In Fontinalis, as well as in many acrocarpous groups, cell rows form a broad angle, which corresponds also to rather small and short apical cells (cf. Figs. 8, 11, 16).

This arrangement allows to form a very homogeneous cells structure within the stem that is likely important for an easy stem elongation, admitting branch initial shift up to 3-5(-8) millimeters above the leaf axil where it starts to develop (at stage shown in Fig. 17). 
A broad angle between cell rows and the shoot axis, however, may result in a problem of attachment of a branch to the stem, as the branch base has to be obconic in shape; sections of lateral parts of branch primordia may illustrate this pattern (Figs. 19A, 24H).

The solution of this problem is likely correlated with the development of much larger and apparently firm-walled cells. Such cells can be seen already at the early stage of primordium development (19G), and with time similar cells fill the whole volume at base of the branch primordium (Figs. 36-37), forming a slightly lighter area on stem around the branch base (Figs. 3, 6). This branch 'foot' seems to be formed by cells of branch leaves bases, although the 1 st and $2 \mathrm{~d}$ branch leaves usually do not participate in it, as the second branch leaf is commonly sitting along the border of this 'foot' area (Figs. 35A, B).

Thus the branch foot seems to be homologous to a multistratose leaf base. An extensive bistratose area at the base of Fontinalis leaves was noted and discussed by Allen (1983). The present study reveals a number of 3-5-stratose leaf bases even in slender apical parts. The ability to additional divisions results in a specific tissue at the leaf base where the stem-leaf boundary is not clear. This structure has obviously a quite important mechanical significance for the plants which are often affected by strong water current.

So, the naked branch bases of Fontinalis should not be treated as homologous to that in, e.g., the Plagiotheciaceae and Hookeriaceae. These two families are often characterized by the absence of pseudoparaphyllia (often considered the same as proximal branch leaves), due to a leafless proximal parts of branches. However their development (briefly discussed by Ignatov \& Hedenäs, 2007) is very different despite similarity in mature plants.

\section{ACKNOWLEDGEMENTS}

We are grateful to A. Ivanova for improving the English of the manuscript. The work was partly supported by RFBR 10-04-00678.

\section{LITERATURE CITED}

AKIYAMA, H. \& N. NISHIMURA 1993. Further studies of branch buds in mosses; «Pseudoparaphyllia» and «Scaly leaves». - J. Plant Res. 106: 101-108.

ALLEN, B.H. 1983. On the costa in Fontinalis (Musci). Lindbergia 9: 37-40
BERTHIER, J. 1971 [1972]. Recherches sur la structure et le développement de l'apex du gamétophyte feuillé des mousses. - Rev. Bryol. Lichénol. 38: 421-551.

CORRENS, C. 1899. Ueber Scheitelwachstum, Blattstellung und Astanlagen des Laubmossstämmchens. - In: Schwendener, S. Botanische Untersuchungen. Berlin, Verlag von Gebrüder Borstraeger: 385-410.

FREY W. 1970 [1971]. Blattentwicklung bei Laubmoosen. - Nova Hedwigia 20: 463-556.

GLIME, J.M. 1987a. Temperature optime of Fontinalis novae-angliae: implications for its distribution. - Symp. Biol. Hungarica 35: 569-576.

GLIME, J.M. 1987b. Growth model for Fontinalis duriaei based on temperatureand flow condition. - J. Hattori Bot. Lab. 62: 101-109.

GLIME, J.M. \& G. REYRMAEKERS 1987. Temperature effect on branch and rhizoid production in six species of Fontinalis. - J. Bryol. 14: 779-790.

GOFFINET, B., W.R. BUCK \& A. J. SHAW 2009.Morphology, anatomy, and classification of the Bryophyta. - In: Goffinet, B. \& A. J. Shaw (eds.) Bryophyte Biology, $2 d$ ed. Cambridge University Press: Cambridge: $55-138$.

IGNATOV, M.S. 1999. Bryophyte flora of the Huon Peninsula, Papua New Guinea. LXIII. On the pseudoparaphyllia in Brachytheciaceae and Meteoriaceae (Musci). - Acta Bot. Fennica 165: 73-83.

IGNATOV, M.S. \& L. HEDENÄS. 2007. Homologies of stem structures in pleurocarpous mosses, especially of pseudoparaphyllia and similar organs. - In: Newton, A.E. \& R. Tangney (eds.) Pleurocarpous mosses: systematics and evolution. CRC Press, Boca Raton-London-New York (Systematic Association Special Volume 71): $269-286$

LEITGEB, H. 1868. Wachstum des Stammchens von Fontinalis. - Sitz. d. K. Ak. Wiss. Math. Natur. 57(1): 308-342 [pages from reprint].

LORENZ, P.G. 1864. Studien über Bau and Entwicklungsgeschichte der Laumboose. - In: Lorentz, P.G. (ed.) Moosstudien. Leipzig, Verlag W.Engelmann. 1-36+4 Tabs.

MÜLLER, C. (BEROL) 1898. Musci (Laubmoose). Fortpflanzungsverhältnisse und Entwiklungsgeschichte. In Engler, A. \& K. Prantl (eds.) Die Naturlichen Pflanzenfamilien. Leipzig, Verlag W.Engelmann 1(3): 155202.

RUHLAND, W. 1924. Musci (Allgemeiner Teil). - In Engler, A. \& K. Prantl (eds.) Die Naturlichen Pflanzenfamilien, 2 Aufl. Leipzig, Verlag W.Engelmann 10: 1105 (2 Aufl., Leipzig).

SPIRINA, U.N. \& M.S. IGNATOV 2008. Branch development and pseudoparaphyllia of Hypnum cupressiforme (Hypnales, Musci). - Arctoa 17: 139-160.

SPIRINA, U.N. \& M.S. IGNATOV 2010. On the branch development in Leucodon (Leucodontaceae, Bryophyta). - Arctoa 19: 139-150. 